\title{
Secondary resources at abandoned mine tailings, Giyani Greenstone Belt, Limpopo province of South Africa
}

\author{
LT Mangwaya University of Venda, South Africa \\ C Muzerengi University of Mpumalanga, South Africa \\ K Madi University of Mpumalanga, South Africa
}

\begin{abstract}
Mining waste are materials that result from the exploration, mining and processing of substances and can consist of natural materials, processed to varying degrees during the ore-processing and enrichment phases, and possibly containing chemical, inorganic and organic additives. Evaluation of the REEs potential of the Klein Letaba tailings dam was envisaged to assist in the containment at the currently un-rehabilitated mine tailings material. These tailings are a concern to the livelihood of nearby communities in the Giyani area due to their threat to water and soil quality. The methodologies used in this study consist of sampling, sample preparation and analysis using $X$-ray spectrometry technique and calculation of the tonnage of the tailings material using the Trapezoidal rule method. The results indicated that the REE abundance at the tailings dump in their decreasing concentration were $\mathrm{Yb}>\mathrm{La}>\mathrm{Ce}>\mathrm{Gd}>\mathrm{Sm}>\mathrm{Dy}>\mathrm{Y}>\mathrm{Er}>\mathrm{Tb}>\mathrm{Eu}>\mathrm{Sc}$. The tailings dam was found to have significant levels of both LREES and HREEs, which are above the upper continental crust thresholds. For instance, the HREEs $G d, D y$, and $Y b$ were almost 10 times or more than the crustal abundances and this being 56, 46 and $17 \mathrm{mg} / \mathrm{kg}$ respectively. The LREEs and HREEs had also a total concentration 602 and $769 \mathrm{mg} / \mathrm{kg}$ respectively. The calculated volume of the tailings material was found to be 527,081 $\mathrm{m} 3$ and the tonnage was derived to be 1,291 349.0 tons of tailings material at the site. Consequently, the total LREEs and HREEs contained in the material was estimated to be 843 tons and worth re-evaluating. The paper uses REES at this study site to illustrate how other un-rehabilitated sites can be re-evaluated and attract investment towards exploiting them and subsequently assisting in tailings containment. However, the REEs at Klein Letaba tailings dam was found to be uneconomic to exploit under the current prices and technology.
\end{abstract}

Keywords: Rare earth elements, re-evaluation, rehabilitation, Giyani greenstone belt

\section{Introduction}

The Giyani Greenstone Belt (GGB) situated in the north-eastern part of the Limpopo Province in South Africa is home to abandoned mine sites. These mine sites are a constant danger to nearby communities due to the risks associated with tailings dam, disused mine shafts, pit lakes and dilapidated mine buildings (Mhlongo et al., 2020). According to Steenkamp and Clark-Mostert (2012), the five largest of the inactive mines which operated in the belt include Franke, Birthday, Louis Moore, Klein Letaba and Fumani. Communities in the vicinity of various tailing dams in the GGB are under threat due to a great potential for problems arising from the un-rehabilitated gold mine tailings such as elevated dust levels, acid mine drainage, landslides, slumps and downward leaching of metals and processing chemicals, which may subsequently contaminate soil and underground water sources. Matovheke and Muzerengi (2018) reported elevated levels of $\mathrm{Pb}, \mathrm{Zn}, \mathrm{Cd}$ and As in the agricultural soils surrounding the Klein Letaba gold mine tailings dam. Elevated levels of $\mathrm{Pb}, \mathrm{Cr}, \mathrm{Cd}, \mathrm{As}$ and $\mathrm{Zn}$ in soils in the vicinity of the abandoned Mandonsi mine in the belt have also been reported by Mulugisi et al. (2009) and Mitileni et al. (2011).

Mine tailings have been reported to be a cause of plumes of dust, which may cause asthma, chronic bronchitis, chronic cough, emphysema and pneumonia to nearby communities (Beaudry, 2018). Although many studies have focused on a multitude of metals contained in the GGB tailings material, studies have overlooked other metals such as the rare earth elements (REEs). The mobility and possible impact of REEs on 
ecosystems are still relatively unknown and thus, potential risks to the environment and human health cannot be currently predicated. Elsewhere, study of the California gold tailings has reported gold mine tailings as mother lode of REEs (Farnahm, 2013). If the REEs could be extracted from previously mined ore, the environmental hazards of new mines and mining waste can be mitigated. According to Hoatson et al. (2011), REEs in Australia are associated with igneous, sedimentary, and metamorphic rocks from a wide range of geological settings.

The REEs are vital to some of the world's fastest growing markets for catalysts, magnets, ceramics, medical equipment, many defence applications and electronics. They underpin technologies that are critical for clean energy, transport and communication (Haque et al., 2014). There are fewer than twenty large companies that trade REEs, and these are distributed to a handful of countries such as China, Canada, Australia, USA, Russia, India and Japan. China is the biggest supplier of REEs in the world, while United States, Japan and Germany are the biggest importers (Roskill, 2015). About $95 \%$ of all the world's REEs resources occur in three minerals, which are bastnasite $\left(\mathrm{CeCO}_{3}(\mathrm{OH}, \mathrm{F})\right.$, monazite $(\mathrm{Ce}, \mathrm{La}) \mathrm{PO}_{4}$ and xenotime $\left(\mathrm{YPO}_{4}\right)$.

At Klein Letaba mine, huge piles of tailings were improperly disposed and left on the surface after closure of the mine around the 1990s. The numerous negative impacts associated with mine tailings near communities and coupled with huge rehabilitation cost presents a challenge to the local and national authorities. Consequently, any move towards exploiting these tailings material is a plausible initiative which may assist in the containment of the tailings material. This study seeks to investigate REEs concentrations at the Klein Letaba gold mine tailings dam. The possible recovery of REEs from the huge mine tailing dams is an exciting novel initiative for the area representing a dramatic paradigm shift for exploiting mine waste and consequently assisting in rehabilitating mine dump sites.

\section{Study Area}

The Klein Letaba gold mine tailings dam is situated on the south-western portion of the GGB about $20 \mathrm{~km}$ south-west of the present-day town of Giyani and roughly $85 \mathrm{~km}$ west of the Kruger national park. It is located between the latitudes $23^{\circ} 17^{\prime} 38^{\prime \prime} S$ and $23^{\circ} 17^{\prime} 48^{\prime \prime} S$ and longitudes $30^{\circ} 33^{\prime} 07^{\prime \prime} \mathrm{E}$ and $30^{\circ} 36^{\prime} 25^{\prime \prime} \mathrm{E}$ (Figure. 1).

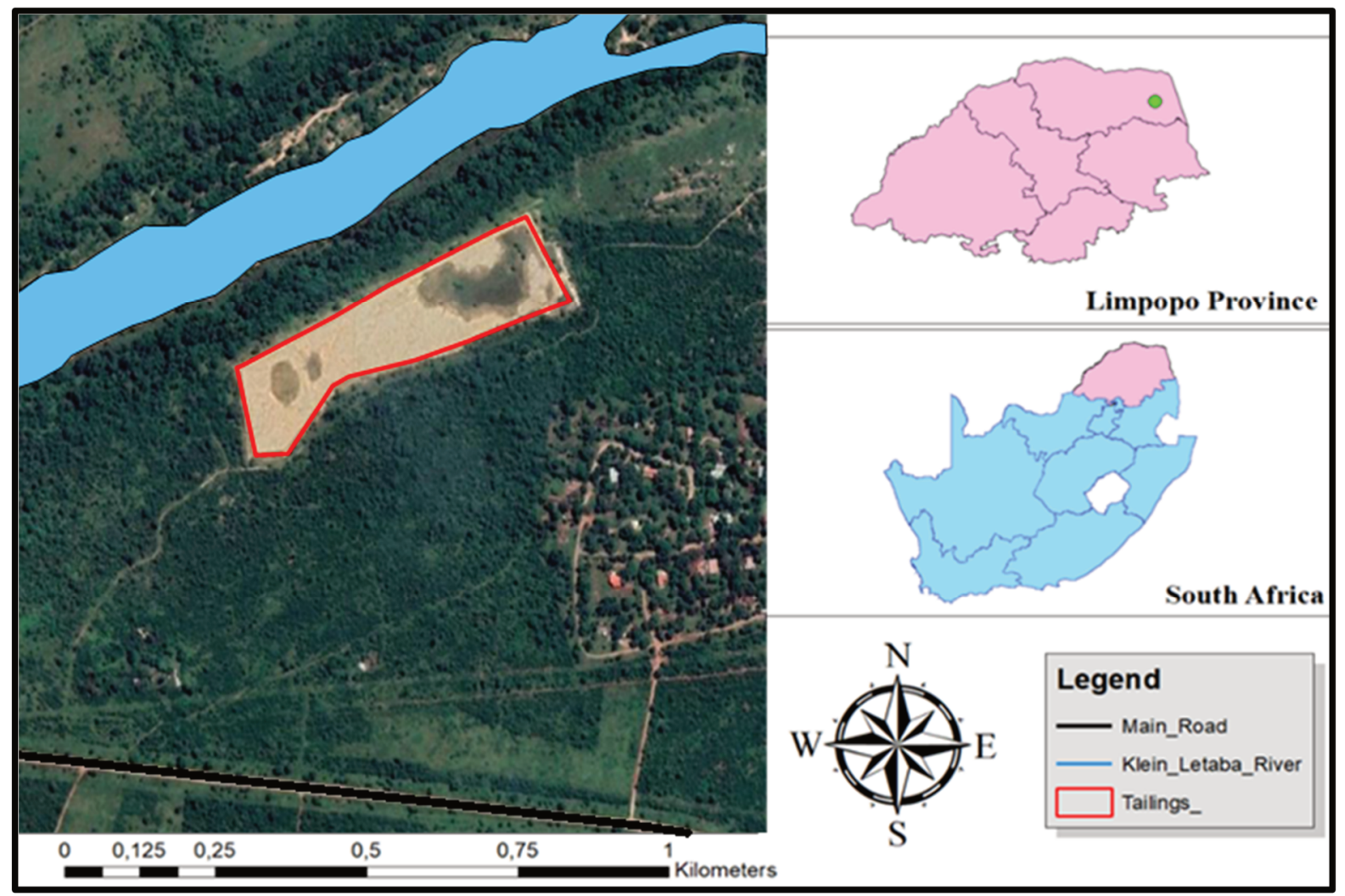

Figure 1 A map showing the location of the Klein Letaba gold mine tailings dam 


\subsection{Geological setting}

The GGB which trends from south-west towards the north-east is well known for its gold mineralisation and it occupies the north-eastern edge of the Kaapvaal Craton. It has got an approximate length and width of 70 and $15 \mathrm{~km}$ respectively. The belt is of Archean age and the lithological succession has been designated as the Giyani Group of the Swazian Supergroup (SACS, 1980). Generally, the GGB is poorly exposed hence there has been no attempt to correlated various units across the belt or to establish stratigraphic units (McCourt and Reenen, 1992). According to Brandl et al. (2006), the GGB appears to be dominated by mafic rocks, ultramafic and minimal felsic schists, iron-formations and meta-sediments. Quartz-biotite, garnetiferous Fe-rich quartzamphibole schists, and quartz-muscovite are the minor metasedimentary rocks in the belt (Pretorius et al., 1988). On its southern and western part, the GGB bifurcates into two narrower arms of 3-5 km width with an outcrop length more than $50 \mathrm{~km}$ (McCourt and Van Reenen, 1992). Prinsloo (1977) has termed these linear greenstone assemblages, the Khavagari arm (in the north) and Lwaji arm (in the south). The northern part of the belt is composed mainly of tremolite-actinolite schist, amphibolites, and banded iron formation, while the southern part consists mainly of amphibolites, banded iron formation, tremolite-actinolite schist, and quartz-sericite schist (Gan and Van Reenen, 1995).

An envelope of migmatitic gneisses surrounds the GGB (McCourt and Reenen, 1992) and a few localities where contacts are exposed tectonically interleaved greenstones and gneisses can be seen (Brandl et al., 2006). According to Potgieter and de Villiers (1986), the auriferous unit contains the banded iron-formation, amphibolites, and tremolite-actinolite schist. Geophysical modelling undertaken by Kleywegt et al. (1987) indicated a shallow structure of about $1.5 \mathrm{~km}$ depth with maximum depth of $3 \mathrm{~km}$ towards its SE margin of the belt. Micaceous quartzite, iron formation and a spotted ultramafic rock occupy the far northeast region of the belt (Pretorius, 1988).

\subsection{Sampling and analysis}

A total of 20 samples were collected from the tailings dam along five lines oriented approximately northsouth with 25 metres as sampling interval using a hand auger and samples were subsequently transported to the laboratory for analysis. Sampling implements and other work surfaces were thoroughly cleaned between samples during sampling, preparations and analysis. A riffle splitter was used to split each of the 20 samples to smaller portions for drying and milling using a Vacutec drying Oven and Retsch, RS 200 milling machine.

The samples were then prepared as pressed powder pellets with a binding agent, boric acid. Approximately $10 \mathrm{~g}$ of the milled powder were pressed in aluminium cups ( $40 \mathrm{~mm}$ in diameter) on a bed of $2.5 \mathrm{~g}$ boric acid while applying a pressure of 30-40 tons for 20 seconds using a hand operated press. An S2 Ranger XRF instrument was employed to analyse the REEs and a set of 6 reference standards were used to set up calibration for the instrument. The analyses were carried out in duplicate for the 20 samples for low rare earth elements (LREEs) La, Ce, Sm, Eu, Sc, and high rare earth elements (HREEs) were Yb, Gd, Dy, Y, Er and Tb.

\subsection{Determining REE tonnage at Klein Letaba}

The authors employed the Trapezoidal Rule for area and volumes method in order to obtain an estimate of the tonnage of the total tailings contained at Klein Letaba. According to Schofiel and Breach (2007), and Chandra (2005), areas and volumes of enclosed by irregular boundaries like the mine tailings or stockpiles can be accurately estimated by the Trapezoidal rule method. In order to calculate total tonnage of the tailings material, the area was divided into a number of trapezoids with the boundaries assumed to be straight at the adjacent offsets. Consequently, the tailings dam was subdivided into two segments (segment $A$ and $B$ ) comprising of and 9 and 8 trapezoids with total lengths of 120.0 and $330.0 \mathrm{~m}$ respectively (Figure 2 ). The two segments were made up of 10 and 8 offsets of varying length and had uniform width among them of 15.0 and $33.0 \mathrm{~m}$ respectively. By using this method, area of each trapezoid was determined and combined to derive the total area. The following formula was used: 


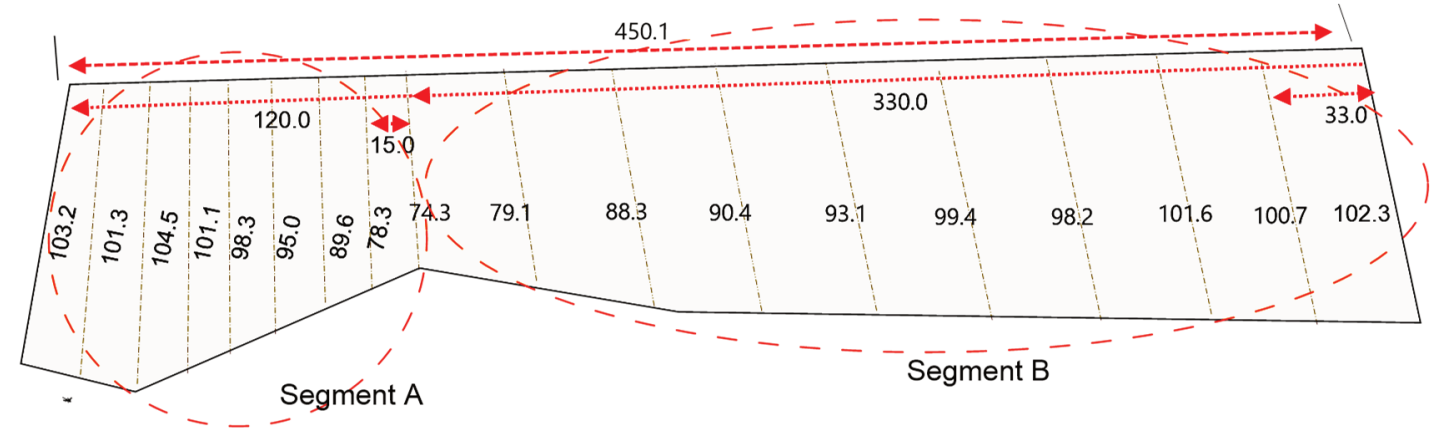

Figure 2 A Sketch of how the tailings dam was demarcated for area and volume calculation.

Using the equation above, the total area for the segments were found to be $39043 \mathrm{~m}^{2}$. In order to obtain the total volume of the material, the height of the tailings dam was measured and found to be $13.5 \mathrm{~m}$. Therefore, using area obtained above, the volume of the tailings material maybe estimated as follows;

Volume of earth work, $V=A^{*} L$, where $L$ is equivalent to the height obtained and being $13.5 \mathrm{~m}$. Therefore, the total volume was found to be $527,081 \mathrm{~m}^{3}\left(39,043 \mathrm{~m}^{2} \times 13.5 \mathrm{~m}\right)$. Subsequently, the volume obtained was converted to tonnage and this was done by measuring the density of the tailings material which was found to be $2.45 \mathrm{~g} / \mathrm{cm}^{3}$. Using this data, the tonnage of tailings was calculated as:

Density $=\frac{\text { Mass }}{\text { Volume }}$......

Tonnage of material $=1,291,349$ tons (Density $x$ tailings volume).

\section{$4 \quad$ Results and Discussion}

\subsection{Statistical analysis}

Summary statistics of geochemical data of the analysed REEs are shown below (Table 1). REEs in their order of decreasing mean concentration were: $\mathrm{Yb}>\mathrm{La}>\mathrm{Ce}>\mathrm{Gd}>\mathrm{Sm}>\mathrm{Dy}>\mathrm{Y}>\mathrm{Er}>\mathrm{Tb}>\mathrm{Eu}>\mathrm{Sc}$. The other REEs such as Ho, Tm, Pr, Nd, Pm and Sc were below the instrument's detection limit of $<1 \mathrm{ppm}$. The total REEs concentration ranged from 303 to $1371 \mathrm{mg} / \mathrm{kg}$. HREEs concentration was much higher with a mean concentration of $390 \mathrm{mg} / \mathrm{kg}$. Cerium and La had the highest concentration of 252 and $266 \mathrm{mg} / \mathrm{kg}$ respectively whilst, Sc was lowest with $0.5 \mathrm{mg} / \mathrm{kg}$. The average total content of REEs (LREE) was $674 \mathrm{mg} / \mathrm{kg}$ with a range of $105 \mathrm{mg} / \mathrm{kg}$.

The study used coefficient of variation (CV) to investigate the variability of the data. Low CV values correspond to a homogeneous distribution whilst, high $\mathrm{CV}$ values represents heterogenous distribution. The CVs of all REEs were relatively low with a minimum of 7 and consequently, indicating a homogeneous distribution of the REEs in the tailings material. However, the LREEs were less homogenous than the REEs with mean CV values of 37.7 and 19.4 respectively. The concentration range for most of the REEs were low and therefore indicating low variability within the tailings material. In general, HREEs are more likely to have more mobility than LREEs and thus, LREEs are enriched and HREEs are depleted gradually during the migration processes as reported by Masto et al. (2011). According to Edahbi (2017), REEs are associated with silicates, carbonates, fluo-carbonates, oxides, phosphates, and sulfates bearing lithologies and these are prevalent in the Giyani Greenstone belt. The LREE/HREE ratio ranged largely from 0.61 to 0.84 with an average of 0.73 . The LREE/HREE ratio showed that the content of LREE does not vary significantly than that of HREE in the Klein Letaba mine tailings. The spatial distribution of REEs is useful in assessing the possible sources of REEs enrichment and also to identify areas with anomalous REEs concentration. Apart from Sc, $Y$ and $\mathrm{Ce}$, the mean REEs concentration in the tailings dam was two or more times higher than the UCC averages. 
Table 1 Statistical data of the analysed REEs at Klein Letaba tailings dam (max and min concentration in $\mathrm{mg} / \mathrm{kg}$ )

\begin{tabular}{|c|c|c|c|c|c|c|c|}
\hline REE & Min & Max & Range & Mean & SD & $\% \mathrm{CV}$ & UCC \\
\hline Sc & 0.4 & 0.5 & 0.1 & 0.5 & 0.05 & 11.4 & 7 \\
\hline Y & 7.2 & 11.5 & 4.3 & 8.7 & 1.1 & 12.9 & 21 \\
\hline La & 98.5 & 266.1 & 167.6 & 167.0 & 40.04 & 24.0 & 30 \\
\hline $\mathrm{Ce}$ & 5.2 & 252.1 & 246.9 & 62.3 & 65.00 & 104.3 & 64 \\
\hline Sm & 9.4 & 81.2 & 71.8 & 53.2 & 18.23 & 34.3 & 4.5 \\
\hline $\mathrm{Eu}$ & 1.5 & 2.0 & 0.5 & 1.8 & 0.13 & 7.0 & 0.88 \\
\hline $\mathrm{Gd}$ & 35.8 & 70.7 & 34.9 & 55.9 & 9.45 & 16.9 & 3.8 \\
\hline $\mathrm{Tb}$ & 2.5 & 5.3 & 2.8 & 4.2 & 0.84 & 20.2 & 0.64 \\
\hline Dy & 29.1 & 58.4 & 29.3 & 45.5 & 8.77 & 19.3 & 3.5 \\
\hline $\mathrm{Er}$ & 4.5 & 8.9 & 4.4 & 7.2 & 1.34 & 18.8 & 2.3 \\
\hline $\mathrm{Yb}$ & 6.77 & 38.1 & 17.6 & 16.7 & 11.3 & 28.2 & 2.2 \\
\hline$\sum \mathrm{REE}$ & 303.1 & 1370.7 & 31.3 & 674.3 & 327.5 & & - \\
\hline LREE & 115.0 & 601.9 & 486.9 & 284.8 & 123.4 & & - \\
\hline HREE & 188.1 & 768.8 & 580.7 & 389.5 & 204.1 & & - \\
\hline LREE/HREE & 0.61 & 0.84 & 0.23 & 0.73 & & - & - \\
\hline & \multicolumn{7}{|c|}{$\begin{array}{l}\text { SD, standard deviation; CV, coefficient of variation; UCC, average upper continental crust } \\
\text { (UCC from Castor and Hedrick (2006) }\end{array}$} \\
\hline
\end{tabular}

The P-values between cross pairs of REEs varied from $<0.05$ to $>0.05$ implying that correlation between the cross pairs varied from being statistically significant to insignificant (Table 2). Strong correlation coefficient was observed among pairs such as $\mathrm{La}-\mathrm{Y}, \mathrm{Y}$-Ce, Sc-Tb and Sc-Er with correlation coefficients of $0.78,0.86,0.82$ and 0.77 respectively. The HREEs pairs had P-values $<0.05$ implying a statistically significant correlation between them. Strong correlation between REEs pairs could be attributed to the REEs emanating from the same source.

Table 2 Pearson's correlations between REE concentrations in the surface soil samples $(p<0.05)$

\begin{tabular}{lllllllllll}
\hline & La & Ce & Sm & Eu & Sc & Gd & Tb & Dy & Er & Y \\
\hline Ce & 0.373 & & & & & & & & & \\
$\mathrm{Sm}$ & $<0.001$ & 0.112 & & & & & & & & \\
$\mathrm{Eu}$ & 0.027 & 0.413 & $<0.001$ & & & & & & & \\
$\mathrm{Sc}$ & 0.671 & 0.681 & 0.451 & 0.226 & & & & & & \\
$\mathrm{Gd}$ & $<0.001$ & 0.095 & $<0.001$ & $<0.001$ & 0.500 & & & & & \\
$\mathrm{~Tb}$ & $<0.001$ & 0.112 & $<0.001$ & $<0.001$ & 0.818 & $<0.001$ & & & & \\
$\mathrm{Dy}$ & $<0.001$ & 0.160 & $<0.001$ & $<0.001$ & 0.675 & $<0.001$ & $<0.001$ & & & \\
$\mathrm{Er}$ & $<0.001$ & 0.110 & $<0.001$ & $<0.001$ & 0.774 & $<0.001$ & $<0.001$ & $<0.001$ & & \\
$\mathrm{Y}$ & 0.783 & 0.861 & 0.450 & 0.169 & 0.440 & 0.311 & 0.402 & 0.373 & 0.415 & \\
$\mathrm{Yb}$ & $<0.001$ & 0.129 & $<0.001$ & 0.001 & 0.571 & $<0.001$ & $<0.001$ & $<0.001$ & $<0.001$ & 0.804 \\
\hline
\end{tabular}




\subsection{LREE Concentration}

LREEs in their order of decreasing concentration values were $\mathrm{La}>\mathrm{Ce}>\mathrm{Sm}>\mathrm{Eu}>\mathrm{Sc}$ and their concentration ranged from 0.4 to $266 \mathrm{mg} / \mathrm{kg}$ (Figure 3). Ce and La had the highest concentration of 252 and $266 \mathrm{mg} / \mathrm{kg}$ respectively whilst Sc and Eu indicated maximum concentration of 0.5 and $2.0 \mathrm{mg} / \mathrm{kg}$.
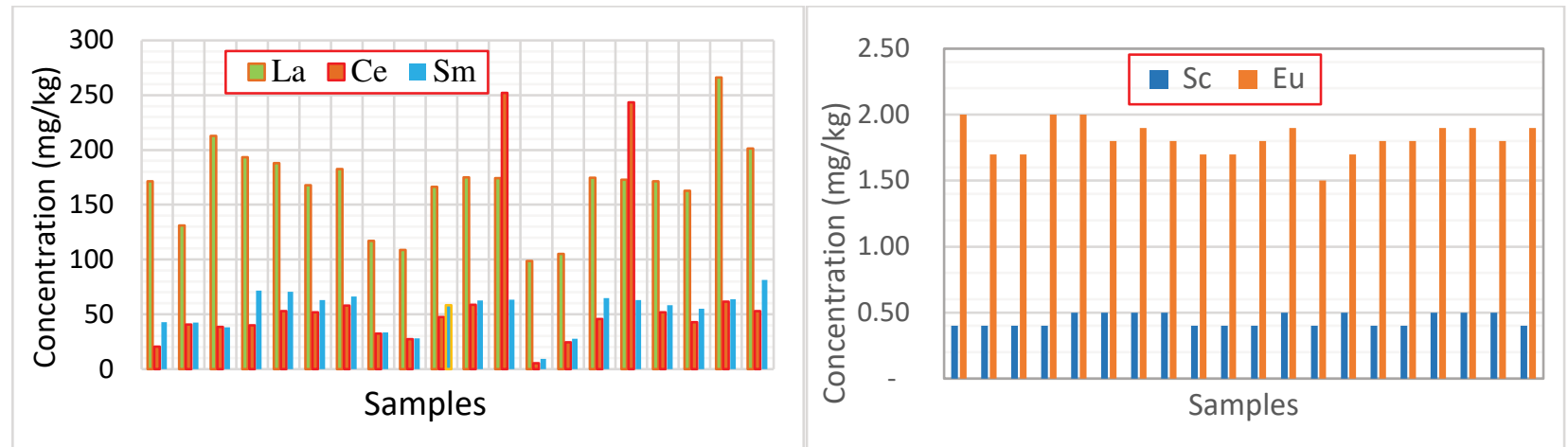

Figure 3 LREE concentration in Klein Letaba gold mine tailings

\subsection{HREE Concentration}

HREEs in their order of decreasing mean concentration values were $\mathrm{Yb}>\mathrm{Gd}>\mathrm{Dy}>\mathrm{Y}>\mathrm{Er}>\mathrm{Tb}$ with variable levels ranging from 2.5 to $71 \mathrm{mg} / \mathrm{kg}$ (Figure 4). The concentrations of the three HREEs (Gd, Dy, and Yb) at Klein Letaba tailings were almost 10 times or more than the crustal abundances and this being 56,46 and $17 \mathrm{mg} / \mathrm{kg}$ respectively. The other $\mathrm{Tb}$ and $\mathrm{Er}$ were at least two times higher than the crustal abundances whilst, $\mathrm{Y}$ concentration was lower than the UCC averages. Considering that these REEs occur as residues of gold mining operations, the accumulation of REEs at the tailings dump is attributed to ore dressing processes which was employed at the mine site.
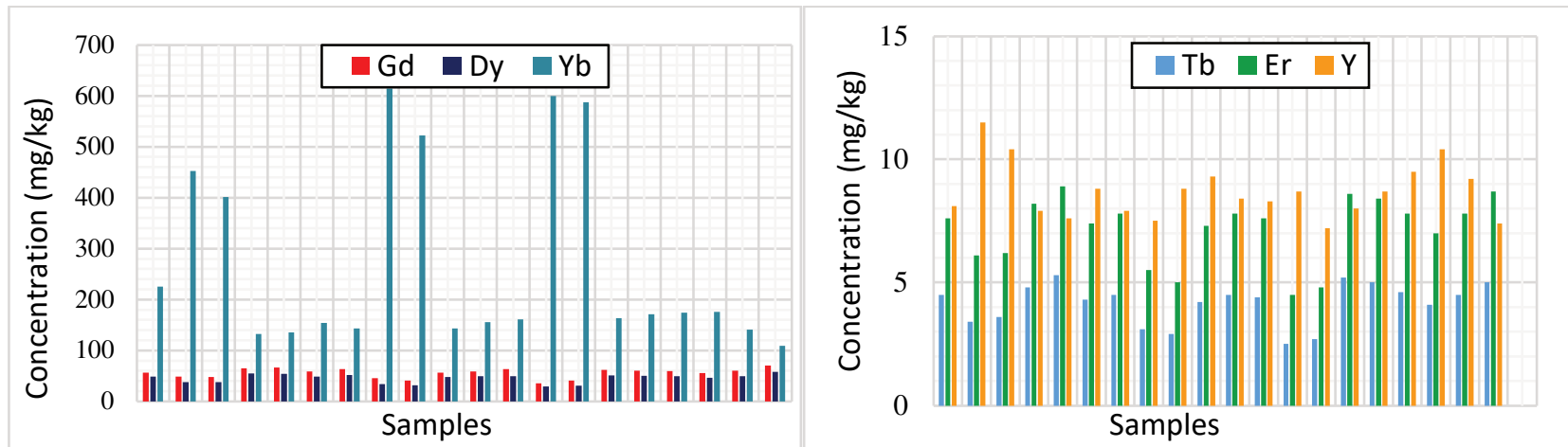

Figure 4 HREE concentration in Klein Letaba gold mine tailings

\subsection{REE differentiation patterns}

The REEs sample concentrations are usually normalized against the composition of the upper continental crust and in this study, normalization was undertaken using McDonough and Sun (1995) normalisation factors. Normalizing the REEs concentration to chondrites is a convenient way for eliminating the OddoHarkins effect and characterize the REEs signature in the Klein Letaba tailings material. The Oddo-Harkins rule states that the cosmic abundance of elements with an even atomic number is greater than that of adjacent elements with odd atomic number. Consequently, the plot of relative atomic abundance against increasing atomic number displays a 'toothed' curve, rather than a smooth line. It should also be noted that the REEs composition and differentiation patterns are not influenced by weathering processes and the REEs concentration remains unchanged. The REEs distribution patterns of the samples were high from the left through elements $\mathrm{Ce}, \mathrm{Sm}$, to Er suggesting that the LREE and HREE are fractionated in different degrees (Figure 5). The REEs exhibited negative $\mathrm{Ce}$, Eu and Er anomaly with a " $\mathrm{V}$ " shape at the REEs normalized 
distribution patterns. With exception of Sc, Ce and Y, REEs concentration at Klein Letaba tailings dam were above the average upper continental crust described by Taylor and McLennan (1995) and similar to that of Humphris (1984) and Henderson (1984).

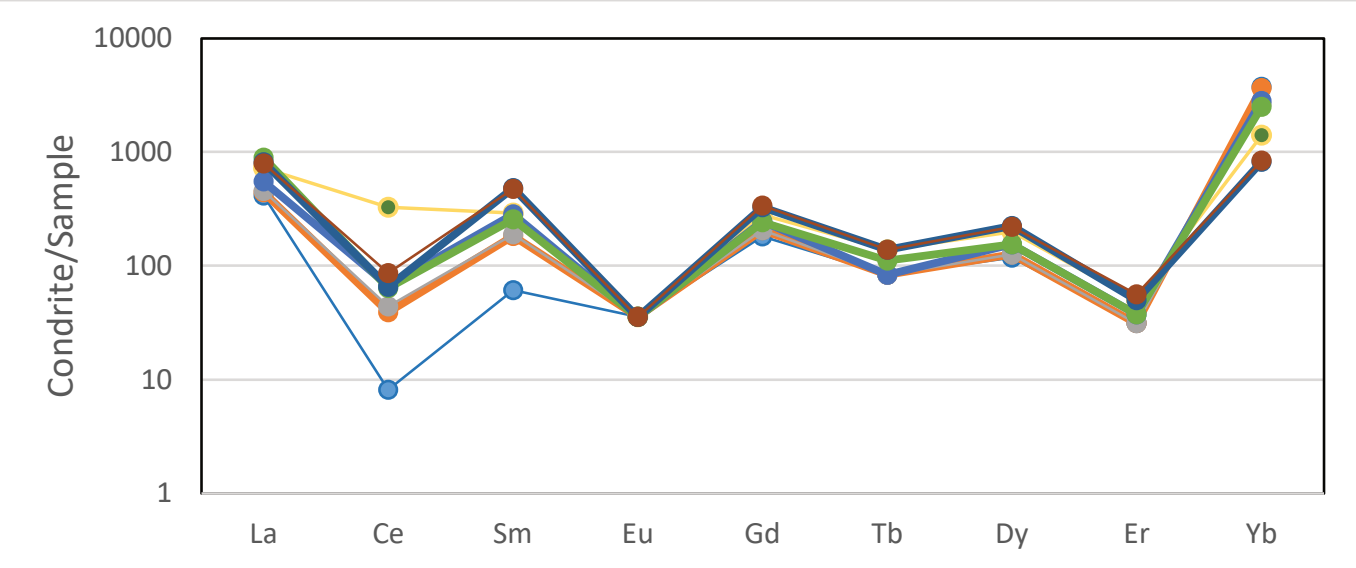

Figure 5 Chondrite normalized REE abundances of the samples collected from Klein Letaba gold mine tailings

\subsection{REEs tonnage at Klein Letaba}

The world has only a few mines that supply the entire world with REEs and most of them are located in China such as the largest Bayan Obo REEs mine (Humphries, 2013). Currently, REEs are mined very cheaply in China as a by-product of iron production at Bayan Obo mine, or from lateritic rich clays in southern China (Hoatson, 2011). The estimated weight of LREEs and HREEs contained in the tailings material may be derived from the average grade of these elements and this being 284.8 and $389.5 \mathrm{mg} / \mathrm{kg}$. This coverts to 368 and 475 tons of LREEs and HREEs at Klein Letaba tailings dam. The total tonnage of 843 tons of REEs at this tailings dump is quite significant. Although the REEs grades are not lucrative for exploitation under the current prices and with current technology, their levels are above the upper continental crust and worth evaluation in detail. Since the tailings material is finely ground $(<2 \mathrm{~mm})$, this will also reduce beneficiation costs which may go a long way towards covering the rehabilitation cost of these mine tailings.

\section{$5 \quad$ Conclusions}

Studies by Salminen et al. (2005) stated that Ce and Sm are normally associated with felsic and mafic igneous rocks and some of these lithologies are also found within the Giyani Greenstone belt. Klein Letaba tailings dam has significant levels of both LREEs and HREEs, which are above the upper continental crust thresholds. According to Taylor and McLennan (1985), the upper crustal abundances of Gd, Dy, and Yb range from 2 to $4 \mathrm{mg} / \mathrm{kg}$. The concentrations of these three HREEs at Klein Letaba tailings were almost 10 times or more than the crustal abundances and this being 56, 46 and $17 \mathrm{mg} / \mathrm{kg}$ respectively. The other $\mathrm{Tb}$ and Er were at least two times higher than the crustal abundances whilst, $Y$ concentration was lower than the UCC averages.

The spatial variability of REEs concentration were low indicating a homogeneous distribution of the REEs in the tailings material. The REEs distribution patterns at Klein Letaba tailings dam as shown by Chondrite normalized REE pattern is in agreement with Wang and Liang (2015) and Laveuf, and Cornu (2009) who reported that individual REEs tend to decrease with increasing atomic number, and REEs with even atomic numbers are more frequent than their neighbours with odd atomic numbers. The LREES/HREEs ratio indicated that the content of LREEs does not vary significantly with HREEs in the Klein Letaba mine tailings. Tailings dams have been a major environmental challenge in the GGB and all over the world and REEs in the tailings material could pollute communal lands in the vicinity of the tailings dam. The estimated tonnage of 843 tons of the REEs in the tailings material is quite significant. It may be worthwhile to stablish the cuff off grade of the REEs whilst considering the available technologies to extract these metals from the Klein tailings dam. 


\section{Acknowledgement}

The author is grateful to the MINECLOSURE 2021 organisers for reviewing and publishing this paper.

\section{References}

Beaudry, F., 2018. Environmental Risks from Mine Tailings. [online]. Available at: https://www.thoughtco.com/environmentaleffects-of-mine-tailings-1204114 [Accessed 9 Jun. 2018].

Brandl, G. Anhaeusser, C. R. and Cloete, M., 2006. Archean Greenstone Belts. In M. R. Johnson, C. R Anhaeusser and R. J. Thomas (eds.): The Geology of South Africa, GSSA/Council for Geoscience, Pretoria, Chapt. 2, pp. 9-47.

Castor, S. B. and Hedrick, J. B. 2006. Rare earth elements, in J. E. Kogel, N. C. Trivedi, J. M. Barker and S. T. Krukowski (ed.), Industrial minerals and rocks: commodities, markets and uses, 7th edn, 769-792, SME.

Chandra, A. M. 2005. Surveying: Problem Solution with Theory and Objective Type Questions. New Delhi: New Age International Pvt. Ltd.

Edahbi, M. Benzaazoua, M. Plante, B. Doire, S. Kormos, L., 2017. Mineralogical characterization using QEMSCAN and leaching potential study of REE within silicate ores: A case study of the Matamec project, Québec, Canada. J. Geochem. Explor, Vol. $185,64-73$.

Farnahm, A., 2013. New Mother Lode for Rare Elements. [online] ABC News. Available at: https://abcnews.go.com/Business/rareearth-elements-mine-tailings/story?id=19739320 [Accessed 9 Jun. 2018].

Gan, S. B. and Van Reenen, D. D., 1995. Geology of Gold Deposits in the Southern Marginal Zone of the Limpopo Belt and the adjacent Sutherland Greenstone Belt, South Africa. South Africa Journal of Geology, 98. vol.3, pp. 263-275.

Haque, N., Hughes, A., Lim, S. and Vernon, C., 2014. Rare earth elements: Overview of mining, mineralogy, uses, sustainability and environmental impact. Resources, vol. 3, no 4, pp. 614-635.

Hoatson, D. M., Jaireth, S., and Miezitis, Y., 2011. The Major Rare-Earth-Element Deposits of Australia: Geological Setting, Exploration, and Resources. Onshore Energy and Minerals Division, Geoscience Australia.

Humphries, M., 2013. Rare earth elements: The global supply chain. Congressional Research Service, CRS Report for Congress, 7$5700,27 \mathrm{pp}$.

Humphris, S., 1984. The mobility of the rare earth elements in the crust. In P. Henderson (ed), Rare Earth Geochemistry. Developments in Geochemistry 2, Elsevier, Amsterdam, 31742.

Henderson, P. (1984). Rare Earth Element Geochemistry. Elsevier, Amsterdam, the Netherlands.

Johnson, M. R., Anhauesser, C. R. and Thomas, R. J., 2006. The Geology of South Africa. Geological Society of South Africa, pp. 34-36.

Kleywegt, R. J., Stettler, E. H, Brandl, G. and Day, R. W., 1987. The Structure of the Giyani Greenstone Belt as Derived from the Geophysical studies. Geophysical Division, Geological Survey of South Africa, South Africa Journal of Geology, 90. vol.3, pp. 282-295.

Laveuf, C. and Cornu, S., 2009. A review on the potentiality of rare earth elements to trace pedogenetic processes. Geoderma, vol. 154, no. 1, pp. 1-12.

McCourt, S and Van Reenen, D., 1992. Structural Geology and Tectonic Setting of the Sutherland Greenstone Belt, Kaapvaal Craton, South Africa, Precambrian Res. vol. 55, pp. 93-110.

Masto, R. E., Ram, L. C., Verma, S. K., Selvi, V. A., George, J., Tripathi, R. C., Srivastava, N. K., Mohanty, D., Jha, S. K., Sinha, A. K. and Sinha, A., 2011. Rare earth elements in soils of Jharia coal field. World Acad Sci Eng Technol, vol. 5, pp. 629-634.

Matovheke, T. and Muzerengi, C., 2018. Pollution Vulnerability of Agricultural Soils near the Klein Letaba Abandoned Gold Mine, Limpopo Province of South Africa. University of Venda, pp. 1-2.

McDonough, W. F. and Sun, S. S., 1995. The composition of the Earth. Chemical geology, vol. 120(3-4), pp. 223-253.

Mhlongo, S. E., Amponsah-Dacosta, F. and Kadyamatimba, A., 2020 'Appraisal of strategies for dealing with the physical hazards of abandoned surface mine excavations: A case study of frankie and nyala mines in South Africa', Minerals, vol. 10 no. 2. doi: $10.3390 / \min 10020145$.

Mulugisi, G., Gumbo, J. R., Dacosta, F, A and Muzerengi, C., 2009. The Use of Indigenous Grass species as part of Rehabilitation of Mine Tailings: A Case study of New Union Gold Mine. Proceedings of the International Mine Water Conference, South Africa, pp. 512-513.

Mitileni, C., Gumbo, J., Muzerengi, C. and Dacosta, F., 2011. The distribution of toxic metals in sediments: Case study of new union gold mine tailings, Limpopo, South Africa. Mine Water-Managing the Challenges; IMWA: Aachen, Germany, pp. 609-614.

Roskill, 2015. Rare earths: Market outlook to 2020, 15th Edition, Roskill, London, 50-263 pp.

Potgieter, G. A., and De Veliers, J. P. R., 1986. Controls of Mineralization at the Fumani Gold Deposit, Sutherland Greenstone Belt. In C. R. Anhaeusser and S. Maske (eds.): Mineral deposits of Southern Africa, Geological Society of South Africa, vol. 1, pp. 198204.

Pretorius, A. I, Van Reenen, D. D and Barton, J. M., 1988. BIF-Hosted Gold Mineralization at the Fumani Mine, Sutherland Greenstone belt, South Africa. South Africa Journal of Geology, vol. 91, pp. 429-430.

Prinsloo, M. C., 1977. The Geology of the Giyani Region, North-eastern Transvaal Showing Easy Economic Mineral Settings. Unpubl. M.Sc. thesis, Rand Africans Univ., Johannesburg, 44 pp.

SACS: South African Committee for Stratigraphy, 1980. Lithostratigraphy of the Republic of South Africa, South West Africa/Namibia, and the Republic of Bophuthatswana, Transkei and Venda. Hand book of Geological Survey of South Africa, vol. 8, 690 pp. 
Salminen, S., Batista, M.J., Bidovec., et al., 2005. FOREGS Geochemical Atlas of Europe. Part 1. Background Information, Methodology, and Maps. Geological Survey of Finland, Espoo.

Schofiel. W, and Breach, M. 2007 Engineering Surveying. 6th edn, Oxford: Elsevier Ltd.

Steenkamp, N. C. and Clark-Mostert, V., 2012. Impact of illegal mining at historic gold mine locations, Giyani Greenstone Belt area, South Africa. In Proceedings of the 9th International Mining History Congress, pp. 1-3.

Taylor, S. R. and McLennan, S. M., 1985. The continental crust: Its composition and evolution. Biackwell. Oxford, pp. 125-133. 